\title{
1 A regulated deficit irrigation strategy for hedgerow olive orchards with
} 2 high plant density

3

4 José E. Fernández ${ }^{1 *}$, Alfonso Perez-Martin ${ }^{1}$, José M. Torres-Ruiz ${ }^{1}$, María V. Cuevas ${ }^{1}$, 5 Celia M. Rodriguez-Dominguez ${ }^{1,2}$, Sheren Elsayed-Farag ${ }^{1}$, Ana Morales-Sillero ${ }^{3}$, José M.

6 García $^{4}$, Virginia Hernandez-Santana ${ }^{1}$, Antonio Diaz-Espejo ${ }^{1}$. 7

Running title: RDI strategy for olive

${ }^{1}$ Irrigation and Crop Ecophysiology Group, Instituto de Recursos Naturales y Agrobiología de Sevilla (IRNAS, CSIC). Avenida Reina Mercedes, n. ${ }^{\circ}$ 10, 41012-Sevilla, Spain

${ }^{2}$ Departamento de Biología Vegetal y Ecología, Universidad de Sevilla, Avda. Reina Mercedes 6, $41012-$ Sevilla, Spain.

${ }^{3}$ Departamento de Ciencias Agroforestales, ETSIA, Universidad de Sevilla, Carretera de Utrera km 1, 41013 Sevilla, Spain

${ }^{4}$ Instituto de la Grasa (IG, CSIC) Avda. Padre Garcia Tejero 4, 41012-Sevilla, Spain

* Corresponding author. Tel.: +34954 624711 (ext. 173); fax: +34 954624002 .

E-mail address: jefer@irnase.csic.es

0 Revised version of PLSO-D-13-00119

1 (Text, 5 Figures, 4 Tables. Electronic supplementary material: 1 Figure, 1 Table)

2 Submitted to Plant and Soil on March 19, 2013 


\section{Abstract}

Background \& Aims. There is not a consensus on the best irrigation approach for superhigh density (SHD) olive orchards. Our aim was to design and test a regulated deficit irrigation (RDI) strategy for a sustainable balance between water saving, tree vigour and oil production.

Methods. We tested our RDI strategy for three years in an 'Arbequina' orchard with 1667 trees $\mathrm{ha}^{-1}$. Two levels of irrigation reduction were applied, 60RDI and 30RDI, scaled to replacing $60 \%$ and $30 \%$, respectively, of the of irrigation needs (IN). We also had a full irrigation (FI) treatment as control, with IN totalling $4701 \mathrm{~m}^{3} \mathrm{ha}^{-1}$

Results. The 30RDI treatment showed the best balance between water saving, tree vigour and oil production. With a yearly irrigation amount (IA) of $1366 \mathrm{~m}^{3} \mathrm{ha}^{-1}$, which meant $72 \%$ water saving as compared to FI, the reduction in oil yield was $26 \%$ only.

Conclusions. Our results, together with recent knowledge on the effect of water stress on fruit development, allowed us to suggest a potentially improved RDI strategy for which a total IA of ca. $2100 \mathrm{~m}^{3} \mathrm{ha}^{-1}$ was calculated. Both some management details and the benefits of this suggested RDI strategy are still to be tested.

Keywords Fruit development; irrigation efficiency; olive oil; super-high density; water productivity

\section{Introduction}

Hedgerow olive orchards with high plant density, also called super-high density (SHD) olive orchards (Vossen et al., 2004), were first tested in Italy (Morettini 1972). The surface covered by these orchards has increased exponentially since the early 1990's, being currently over 100,000 ha worldwide (Rius and Lacarte 2010). Current evidence suggests that a deficit irrigation (DI) strategy could be the best option for SHD olive orchards, since problems derived from excessive tree vigour, common in this type of orchards, can be minimized by reduced irrigation. Thus, controlling growth may lead to a regular distribution of the incident solar radiation into the canopy (Connor, 2006), and helps to keep the trees at a suitable size for the vineyard type straddle-harvesters commonly used in these orchards (León et al., 2007). Substantial water savings can be achieved when a DI 
strategy is properly chosen and applied, without penalizing yield and sometimes improving quality (Moriana et al., 2003; Tognetti et al., 2006, 2008). A wrong, badly managed DI strategy, however, may cause severe water deficit at stages when the crop is most sensitive to water stress, reducing both the yield of the current year and the productive life of the orchard (Fereres and Evans, 2006).

Both sustained deficit irrigation (SDI) and regulated deficit irrigation (RDI) are recommended for olive orchards (Moriana et al., 2003; Iniesta et al., 2009; Ramos and Santos 2009). SDI is based on supplying a fixed fraction of the water needed to replace the crop evapotranspiration $\left(\mathrm{ET}_{\mathrm{c}}\right)$ all throughout the irrigation season (Goldhamer et al., 2006). $\mathrm{RDI}$ consists on replacing $\mathrm{ET}_{\mathrm{c}}$ in the phases of the growing cycle when the crop is more sensitive to water stress, and reducing or even withholding irrigation for the rest of the cycle (Chalmers et al., 1981). For olive orchards with plant densities ranging from ca. 400 to 600 trees $^{-1}{ }^{-1}$, full irrigation (FI) (Testi et al., 2006), SDI (Gucci et al., 2012) and RDI (Patumi et al., 2002; d'Andria et al., 2004) have been tested. It is not clear, however, whether SDI or RDI is the best option for SHD olive orchards, and, if a RDI strategy is chosen, which criteria must be followed for adjusting the irrigation supplies on different phenological stages. Thus, the olive tree is considered to be sensitive to water stress at bloom, beginning of pit hardening and from 2-3 weeks before ripening (Lavee and Wodner, 1991; Moriana et al., 2003; Tognetti et al., 2005). Findings on both the length of the midsummer, low-sensitive period to water stress (Tognetti et al., 2009) and the level of irrigation reduction on that period (Goldhamer 1999; Motilva et al., 2000; Fregapane et al., 2010) have also been published. There is not, however, a consensus on these crucial aspects of irrigation management. In addition, and despite some work on the matter (Gucci et al., 2009; Gómez-del-Campo et al., 2011) there is still a lack of information on how to manage irrigation on the first weeks of fruit development. orchards. Trees in SHD orchards have usually small root zones, i.e. the buffer capacity of the soil is low (Diaz-Espejo et al., 2012). This means that errors on irrigation management could have greater consequences in SHD orchards than in orchards with lower tree densities.

There are examples of a variety of irrigation strategies applied to olive orchards with high plant densities, from supplementary irrigation (Proietti et al., 2012) to full irrigation (Pastor et al., 2007). The works by Grattan et al. (2006) and Berenguer et al. (2006) explored the convenience of SDI with different levels of irrigation reduction. For RDI we found just two papers. In one of them, made with 'Arbequina' trees, the authors 
100 reported that the reduction in irrigation from the end of fruit drop to the beginning of oil 101 synthesis had little effect on oil production (Gómez-del-Campo, 2011). This does not agree with the need of avoiding water deficit on the first weeks of pit hardening, when active cellular division occurs in the fruits, reported by Gucci et al. (2009), among others. In the other paper, irrigation supplies for 'Cornicabra' olive trees were reduced from mid-August to late September, according to measurements of soil water potential. The phenological stages of the trees were not taken into account for adjusting irrigation (Gómez-del-Campo, 2010). Current knowledge, therefore, is not enough for the management of irrigation in SHD olive orchards. We hypothesized that a properly designed RDI strategy in SHD olive orchards would lead to a controlled tree water stress, which would not unacceptably penalize oil production, but would lead to a more reduced canopy, beneficial for a long productive life of the orchard.

Our aim was to design and test a RDI strategy for a sustainable balance between water saving, tree vigour and oil production when applied to a SHD olive orchard. Our strategy was intended to achieve high water productivity values at the same time than the risk for shortening the productive life of the orchard, derived from excessive plant vigour, was minimized. We designed the RDI strategy based on knowledge on the sensitivity of the olive tree to water stress at different phenological stages available at the beginning of 2010, when this work began. The RDI strategy was applied with two levels of irrigation reduction in a fully productive SHD 'Arbequina' olive orchard. After three years of testing, our results were compared with recent knowledge on the effect of water stress on olive fruit development. This allowed us to suggest some improvements for the RDI strategy. This work is part of a research project in which aspects related both to the use of plantbased indicators for irrigation scheduling (Fernández et al., 2011; Cuevas et al., 2012; Rodriguez-Dominguez et al., 2012) and the development of a mechanistic model to asses water needs in SHD olive orchards (Diaz-Espejo et al., 2012) are being also considered.

\section{Materials and Methods}

Orchard characteristics

131 The experiments were made from 2010 to 2012, in a commercial SHD olive orchard near

132 Seville, southwest Spain $\left(37^{\circ} 15^{\prime} \mathrm{N},-5^{\circ} 48^{\prime} \mathrm{W}\right)$. Trees were 4-year-old in 2010. They were 
133 'Arbequina' trees planted at $4 \mathrm{~m} \times 1.5 \mathrm{~m}\left(1667\right.$ trees $\left.\mathrm{ha}^{-1}\right)$, in rows oriented N-NE to S-

$134 \mathrm{SW}$. The trees, with a single trunk and branches from 0.6 to $0.7 \mathrm{~m}$ above ground, were manually pruned in December-January each year. Lateral branches with excessive growth were cut close to their insertion point in the main trunk, and vertical branches at the top of the trees were cut to keep a maximum size of the canopy compatible with the mechanical harvester (ca. $2.10 \mathrm{~m}$ wide and ca. $2.5 \mathrm{~m}$ high). Weeds below the trees were controlled with nonresidual herbicides. Grass cover was kept among tree rows, with several cuts during the dry seasons. The orchard soil (Arenic Albaqualf, USDA 2010) had a sandy loam top layer (Table 1) and a sandy clay layer downwards. The trees were planted at the top of ca. $0.4 \mathrm{~m}$ high ridges. The average depth from the highest part of the ridges to the clayey soil layer was $0.6 \mathrm{~m}$. Diaz-Espejo et al. (2012) found an average root area per tree of 2.65 $\mathrm{m}^{2}$ and $0.45 \mathrm{~m}$ maximum depth of the root systems. The average soil volume wetted by irrigation was $0.12 \mathrm{~m}^{3}$ per tree. The soil below the top sandy soil layer had clayey texture $(60.9 \%$ sand, $37.1 \%$ clay and $2.0 \%$ silt $)$, high dry bulk density $\left(\rho=1.82 \mathrm{Mg} \mathrm{m}^{-3}\right)$ and low soil hydraulic conductivity in the range near saturation $\left(K_{\text {sat }}=3.54 \pm 1.09 \mathrm{~cm} \mathrm{day}^{-1}\right)$. These characteristics favoured waterlogging conditions during the rainy season and high resistance to penetration during the dry season (Cuevas et al., 2012). Consequently, the subsoil layer was not explored by the roots (Diaz-Espejo et al., 2012).

Climate in the area is Mediterranean, with mild rainy winters and hot, dry summers. Most of the annual rainfall occurs between late September and May. Average values in the area of potential evapotranspiration $\left(\mathrm{ET}_{\mathrm{o}}\right)$ and precipitation $(P)$ were $1541.5 \mathrm{~mm}$ and 534.0 $\mathrm{mm}$, respectively, for the 2002-2012 period. For that period, average maximum $\left(T_{\mathrm{a}, \max }\right)$ and minimum $\left(T_{\mathrm{a}, \min }\right)$ air temperature were $24.9{ }^{\circ} \mathrm{C}$ and $10.7{ }^{\circ} \mathrm{C}$, respectively. The hottest months are July and August. $T_{\mathrm{a}, \max }$ values over $40{ }^{\circ} \mathrm{C}$ are recorded nearly every year, with peak values rarely over $45{ }^{\circ} \mathrm{C}$. The coolest months are December and January. Temperatures below $0{ }^{\circ} \mathrm{C}$ are recorded every year, with minimum values rarely below -5

The RDI strategy

We considered three periods along the olive growing cycle on which the crop is more sensitive to water stress (Fig. 1). Period 1 goes from the last stages of floral development to full bloom. Enough water supply on these days favours flower fertilization (Rapoport and 
166 Rallo, 1991). In the area, period 1 usually occurs in mid-April, when rainfall is usually enough to replace $\mathrm{ET}_{\mathrm{c}}$, so irrigation is rarely needed. Period 2 occurs at the end of the first phase of fruit development, i.e. on the week ca. 6 to 10 after full bloom (AFB) (Rallo and Rapoport 2001). In our area this usually occurs in June. Water deficit at this period has

170 been reported to reduce fruit size (Rapoport et al., 2004). Period 3 refers to a period of ca.

1713 weeks prior to ripening, when a marked increase in oil accumulation occurs, after the 172 midsummer period of high atmospheric demand. Period 3 occurs in the area from late 173 August to mid-September. At this period 3 the olive tree is very sensitive to water stress 174 (Lavee and Wodner, 1991; Moriana et al., 2003; Tognetti et al., 2005). As shown in Fig. 1, with our RDI strategy irrigation supplies must replace or be close to the crop water needs at periods 1, 2 and 3. From late June to late August, i.e. between periods 2 and 3, the olive tree is highly resistant to drought, so irrigation supplies can be markedly reduced (Alegre et al., 2002; Moriana et al., 2003; Iniesta et al., 2009). A severe water restriction at this time of the year can highly affect fruit growth (Gucci et al. 2009), but the olive tree has an outstanding capacity for recovering from water stress provided that enough water is supplied on period 3 (Lavee et al., 1990; Moriana et al., 2007). The rainy season in the area starts usually on late September, so irrigation from the end of period 3 to harvesting, onlate October or early November, will depend on rainfall.

Irrigation treatments

In 2010 we started the irrigation season on May 18, day of year (DOY) 138. From that day to May 31 we irrigated all trees in the orchard to replace $100 \%$ of the irrigation needs (IN), calculated as $\mathrm{IN}=\mathrm{ET}_{\mathrm{c}}-P_{\mathrm{e}}$, being $\mathrm{ET}_{\mathrm{c}}$ the maximum potential crop evapotranspiration calculated with the crop coefficient approach (Allen et al., 1998) and $P_{\mathrm{e}}$ the effective precipitation calculated as $75 \%$ of the precipitation recorded in the orchard (Orgaz and

192 Fereres, 2001). Details on the ET $_{c}$ calculations are given by Fernández et al. (2011). Two

193 RDI treatments, named 60RDI and 30RDI, were established in the orchard from June 1 194 (DOY 152) to November 2 (DOY 306), the harvesting day. They followed the timing of irrigation detailed in Fig. 1. The treatments were scaled to a total IA of $60 \%$ (60RDI) and $30 \%$ of IN (30RDI). Rainfall in 2010 was enough to replace $\mathrm{ET}_{\mathrm{c}}$ in period 1 (mid-April, data not shown). In period 2 we irrigated daily, with water supplies that amounted to $80 \%$ 
week in 60RDI and one day per week in 30RDI. In total, the IA on that period amounted to $20-30 \%$ of IN in $60 \mathrm{RDI}$ and $10-15 \%$ of IN in 30RDI. In period 3 the 60RDI trees were irrigated daily to replace IN, and the 30RDI trees were irrigated twice per week with IA amounting to $30 \%$ of IN.

For the RDI treatments we used a randomized block design with four $12 \mathrm{~m} \times 16 \mathrm{~m}$ plots per treatment. Each plot contained 8 central trees surrounded by 24 border trees. All measurements were made in central trees. We also had an FI treatment in an additional plot, as a control treatment, in which the trees were daily irrigated to replace $\mathrm{IN}$, all along the irrigation season. In all plots the irrigation system consisted of one drip line per tree row with a $2 \mathrm{~L} \mathrm{~h}^{-1}$ dripper every $0.5 \mathrm{~m}$. The time and frequency of irrigation was input in an irrigation controller (Agronic 2000, Sistemes Electrònics PROGRÉS, S.A., Lleida,

210 Spain), which activated the irrigation pump and the electrovalves to supply the calculated

211 IA. The irrigation system had one caudalimeter per treatment, which recorded the applied

212 IA on each irrigation event.

213 In 2011 and 2012 we applied the same treatments as in 2010, but with four plots for 214 all treatments, including the FI treatment, distributed in a randomized block design. In 2152011 the irrigation season extended from June 7 (DOY 158) to October 24 (DOY 297), 216 two days before harvesting. In 2012 the irrigation season began on June 5 (DOY 156) and 217 ended on October 22 (DOY 295). The harvesting was made on November 13 (DOY 387), 218 but irrigation was not needed from DOY 295 because rainfall was enough to replace $\mathrm{ET}_{\mathrm{c}}$. 219 All trees were fertilized in the same way. We injected an $8 \mathrm{~N}-3 \mathrm{P}-8 \mathrm{~K}+0.05 \% \mathrm{~B}+0.05 \%$ 220 Fe solution into the irrigation system once per week, throughout the three irrigation seasons. The amount of fertilizer was changed every month to match the crop needs (Troncoso et al., 2001). In 2010 and 2011 we supplied $240 \mathrm{~kg} \mathrm{ha}^{-1}$ of $\mathrm{N}$ and $\mathrm{K}, 90 \mathrm{~kg} \mathrm{ha}^{-1}$ of $\mathrm{P}$, and $150 \mathrm{~kg} \mathrm{ha}^{-1}$ of B and Fe. In 2012 fertilizer supplies were increased by $30 \%$, to account for the increase in leaf area (LA) (see the 'Crop performance' section).

Plant measurements

Midday stem water potential ( $\left.\Psi_{\text {stem }}\right)$ was measured once every two weeks during the whole irrigation season of every experimental year. On each measurement day of 2010 we sampled one leaf per tree from two representative trees per plot of each RDI treatment. In the FI plot we sampled two leaves per tree from four trees. In 2011 and 2012 we sampled 
one leaf per tree from two representative trees per plot of each treatment. Leaf sampling was always made at 12.00-13.00 GMT. The leaves, taken from the inner part of the canopy, were wrapped in aluminium foil ca. $2 \mathrm{~h}$ before the measurement of $\Psi_{\text {stem }}$ with a Scholander-type pressure chamber (PMS Instrument Company, Albany, Oregon, USA). Measurements of stomatal conductance were made on the same days and in leaves of the same trees, but at 08.00-09.00 GMT, the time for maximum daily stomatal conductance $\left(g_{\mathrm{s}, \max }\right)$ in olive (Fernández et al., 1997). We sampled the same number of leaves for $g_{\mathrm{s}, \max }$ than for $\Psi_{\text {stem. }}$. We used a Licor LI-6400 portable photosynthesis system (Li-cor, Lincoln NE, USA) with a $2 \mathrm{~cm} \times 3 \mathrm{~cm}$ standard chamber, to measure $g_{\mathrm{s}, \max }$ in the $4^{\text {th }}-5^{\text {th }}$ leaf from the apex of current-year shoots from the outer part of the canopy facing S-E, at ca. $1.5 \mathrm{~m}$ above ground. Measurements were made in sunny days, at ambient light (1100 to 1500 $\left.\mu \mathrm{mol} \mathrm{m} \mathrm{s}^{-1}\right)$ and $\mathrm{CO}_{2}\left(370-400 \mu \mathrm{mol} \mathrm{mol}^{-1}\right)$ conditions. Measurements of leaf area (LA) were made at dawn on the days when $\Psi_{\text {stem }}$ and $g_{\mathrm{s}, \max }$ were measured, with a LAI-2000 Plant Canopy Analyzer (LI-COR, Lincoln, NE, USA). See Cuevas et al. (2012) for details. After each LA measurement we recorded the occurrence of fruit shriveling, leaf rolling and reductions in the angle of the leaf with the stem, main visual symptoms of severe water stress in olive (Schwabe and Lionakis, 1996; Greven et al., 2009).

Leaf samples were taken for nutrient analysis in July each experimental year. About 200 leaves were sampled from the middle portion of current-year shoots all around the canopy of the eight central trees per plot, at ca. $1.5 \mathrm{~m}$ above ground. Samples were washed in distilled water, dried at $70{ }^{\circ} \mathrm{C}$ until constant weight, ground and passed through a 500 mm stainless-steel sieve. $\mathrm{N}$ concentration was determined by Kjeldahl method. Other mineral nutrients $(\mathrm{P}, \mathrm{K}, \mathrm{Ca}, \mathrm{Mg}), \mathrm{Na}$, and trace elements $(\mathrm{Mn}, \mathrm{Zn}, \mathrm{Cu}$ and $\mathrm{B}$ ) were extracted by wet oxidation with $4 \mathrm{~mL}$ of concentrated $\mathrm{HNO}_{3}(65 \% \mathrm{w} / \mathrm{w})$ under pressure in a microwave digester. Analysis of all elements were determined by Inductively Coupled Plasma-Optical Emission Spectrometry (ICP-OES) using a VARIAN ICP 720-ES and expressed on a dry weight basis. The accuracy of the analytical methods was assessed through BCR analysis (Community Bureau of Reference).

Fruit and virgin olive oil (VOO) yields were derived from fruit samples taken from central trees of each plot, on each year's harvesting day. The trees were manually harvested, and total fruits per plot were weighted separately. Immediately after harvesting we took $0.5 \mathrm{~kg}$ fruit samples per plot to determine the pulp/stone ratio. Pulp weight was determined as the difference between fruit and stone weights. We also took a $2 \mathrm{~kg}$ fruit 
sample per plot for oil extraction with an Abencor system (Commercial Abengoa S.A., Seville, Spain) (Martinez et al., 1975).

The recorded fruit and VOO yields together with the total IA supplied to each treatment allowed us to calculate water productivity (WP) values as the amount of marketable product per hectare per unit of supplied water. This does not agree with the standard definition of WP, where the amount of water considered is the actual $\mathrm{ET}_{\mathrm{c}}(\mathrm{Kijne}$ et al. 2003). We, however, did not record the actual $\mathrm{ET}_{\mathrm{c}}$, since water losses by drainage that could have occurred in the experimental plots were not evaluated. Likely, however, the water lost by drainage in the RDI treatments was low.

Soil and weather measurements

We estimated the volumetric soil water content $\left(\theta_{\mathrm{v}}\right)$ in every plot from measurements with a Profile probe (Delta-T Devices Ltd, Cambridge, UK) and two access tubes per plot, at ca. $0.5 \mathrm{~m}$ from the tree trunk. One of the access tubes was at $0.1 \mathrm{~m}$ from a dripper, i.e. in the soil volume wetted by irrigation. The other was at $0.4 \mathrm{~m}$ from the dripper, i.e. in drying soil during the irrigation season. In each access tube we measured $\theta_{\mathrm{v}}$ at $0.1,0.2,0.3,0.4,0.6$ and 1.0 m depths, 1-2 times per week, all along the irrigation seasons. In 2010 we had six access tubes in the FI plot, at the same distances from the tree trunk and from the drippers as in the RDI plots. The Profile probe was calibrated in situ by Fernández et al. (2011). From the estimated $\theta_{\mathrm{v}}$ values we calculated the relative extractable water (REW) in the root zone as REW $=\left(R-R_{\min }\right) /\left(R_{\max }-R_{\min }\right)$, where $R(\mathrm{~mm})$ is the actual soil water content, $R_{\min }(\mathrm{mm})$ the minimum soil water content measured during the experiments, and $R_{\max }$ $(\mathrm{mm})$ is the soil water content at field capacity. Additional $\theta_{\mathrm{v}}$ measurements were made every $10 \mathrm{~min}$, all along the three irrigation seasons, by four Profile probes connected to a CR1000 Campbell datalogger (Campbell Scientific Ltd., Shepshed, UK). These probes were in a 60RDI and a 30RDI plot, at $0.1 \mathrm{~m}$ and $0.4 \mathrm{~m}$ from a dripper on each case.

The daily FAO-56 Penman-Monteith $\mathrm{ET}_{\mathrm{o}}$ values required for calculating $\mathrm{ET}_{\mathrm{c}}$ were collected from a nearby standard weather station belonging to the Agroclimatic Information Network of the Junta of Andalusia. Main weather variables in the orchard were monitored by a Campbell weather station (Campbell Scientific Ltd., Shepshed, UK) that we installed at the beginning of 2010 in the centre of the area covered by the experimental plots, at $40 \mathrm{~m}$ from the closest edge of the orchard. We used a pole for 
installing all meteorological sensors between $2 \mathrm{~m}$ and $3 \mathrm{~m}$ above the canopies. The station recorded 30 min average values of wind speed $(u)$, air temperature $\left(T_{\mathrm{a}}\right)$, air humidity $\left(\mathrm{RH}_{\mathrm{a}}\right)$,

300 global solar radiation $\left(R_{\mathrm{s}}\right)$, net radiation $\left(R_{\mathrm{n}}\right)$, photosynthetically active radiation (PAR), 301 and $P$.

\section{Statistical analysis}

We used linear mixed models (LMM) to analyze the effects of the irrigation treatment (fixed factor) on REW, LA, $\Psi_{\text {stem, }} g_{\mathrm{s}, \max }$, fruit and VOO yield, and pulp/stone ratio as dependent variables for each day of measurements. We used leaf identity within plot as the random factor structure in the $\Psi_{\text {stem }}$ and $g_{\mathrm{s}, \max }$ analyses to describe appropriately our experimental design and deal with the non-independent nature of the spatial experimental design. For fruit and VOO yield analyses we used the sample number within plot as the random factor structure. In REW, LA and pulp/stone ratio analyses the random factor was not necessary as we only have one measurement per plot. When no normal and homocedastic residuals were obtained, appropriate transformation of the variable was used.

314 The model parameters were determined using the restricted maximum likelihood (REML) 315 approach. These analyses were conducted with the R package 'nlme R' (Pinheiro et al. 316 2011).

\section{Results}

Atmospheric demand, water and nutrient supplies and soil water status

Weather conditions during the experimental years were as usual in the area, with the highest $\mathrm{ET}_{\mathrm{o}}$ values from mid-June to late August and decreasing $\mathrm{ET}_{\mathrm{o}}$ values from the beginning of September onwards throughout autumn (Fig. 2a). The highest $R_{\mathrm{S}}$ values were recorded in June (Fig. 2b). Most of the days of the irrigation seasons were clear-sky days. The greatest temperatures were recorded from mid-July to mid-August (Fig. 2c). Total ET and $P$ values, both for the three experimental years and the three irrigation seasons, are given in Table 2. The year 2010 was unusually wet, while both 2011 and 2012 were years on which $P$ values were below the average in the area. The three irrigation seasons were mostly dry. In 2010 and 2012, the first rainy events after the dry season were recorded 
331 from late September, as usual in the area. In 2011 the first significant rainfall event occurred on October 24 (DOY 297). Table 2 shows the total IA per year and treatment, 333 which fitted quite well the aimed \% IN on each treatment. Details on the IA applied to each treatment all along the three irrigation seasons are given in Fig. 3a,b,c.

Values of REW for the FI plots show soil water conditions close to field capacity, all along the three irrigation seasons (Fig. 3d,e,f). A similar situation was observed in all the RDI plots on period 2 (June, Fig. 1). Decreasing REW values were observed in the plots of the two tested RDI treatments between period 2 and period 3, i.e. from early July to late August, in agreement with the reduced IA supplied on that period. For the three experimental years, the IA supplied to the 60RDI plots from the beginning of period 3 (late August) to harvesting was enough to cover IN, which explains the similarities on the REW values calculated for the FI and the 60RDI plots on that period. The 30RDI plots, however, were irrigated on the same period to replace ca. $30 \%$ IN, so REW values for that treatment remained below those in the FI and 60RDI plots.

The water holding capacity of the soil layer explored by the roots, calculated as the difference between the soil water contents at the soil matric potentials of -0.03 MPa (field capacity) and -2.5 MPa (wilting point for olive according to Dichio et al., 2003) was 49.5 $\mathrm{mm}$. The growing cycle began around mid-February each year. Soon after, when both the atmospheric demand and water uptake by the trees were moderate, water in the root zone was depleted to levels close to the readily available water (RAW) in ca. 5 days (Fig. S1a). We assumed a RAW value equivalent to $75 \%$ depletion of the soil water holding capacity (Orgaz and Fereres, 2001). In late July, when the greatest atmospheric demand and water uptake activity were recorded, the soil water of the RDI plots was depleted to the RAW level in ca. 1 day after each irrigation event (Fig. S1b).

The nutrient concentrations in leaves of the three treatments were within the optimum ranges for olive on the three experimental seasons, for all the analysed elements (Table S1). Fertilization, therefore, was enough to avoid any nutrient deficiency in the trees of all treatments.

Plant water status and stomatal conductance

362 Both midday $\Psi_{\text {stem }}$ and $g_{\mathrm{s}, \max }$ have been reported as sensitive indicators of water stress in olive (Moriana and Fereres, 2002; Gómez-del-Campo, 2007; Ben-Gal et al., 2010). Except 
364 for some days in August and early September 2010, midday $\Psi_{\text {stem }}$ values in the FI trees were always over -1.4 MPa, the threshold level for water stress reported for olive trees with high crop load (Moriana et al., 2012) (Fig. 4a,b,c). The recorded $\theta_{\mathrm{v}}$ profiles suggested occasional water losses by drainage in the FI plots, since $\theta_{\mathrm{v}}$ values at the bottom of the root zone were sometimes close to field capacity (data not shown). This agrees both with the IA supplied to the FI trees being slightly over IN (Table 2) and with the sandy nature of the soil. Measurements of midday $\Psi_{\text {stem }}$ in the 60RDI and 30RDI trees showed increasing water stress between periods 2 and 3 (Fig. 1), in agreement with the reduced IA and the decreasing REW values recorded between both periods (Fig. 3). The IA supplied to the 60RDI plots during period 3, similar to those supplied to the FI trees, was enough for the trees to recover from water stress from early September. In the 30RDI trees, however, IA supplied on period 3 was ca. $30 \%$ only of that supplied to the 60 RDI trees, which explains the significant levels of water stress observed in the 30RDI trees in September and October. Altogether, the seasonal dynamics of midday $\Psi_{\text {stem }}$ recorded on the three irrigation seasons (Fig. 4a,b,c) agreed quite well with those of theIA and REW values (Fig. 2).

In the FI trees, $g_{\mathrm{s}, \max }$ was most of the time between 0.2 and $0.3 \mathrm{~mol} \mathrm{~m}^{-2} \mathrm{~s}^{-1}$ (Fig. 4d,e,f). This agrees with values reported by Diaz-Espejo et al. (2006) for 'Manzanilla' olive trees of an orchard nearby when growing under non-limiting environmental conditions. In the RDI treatments $g_{\mathrm{s}, \max }$ decreased with the reduction on IA after period 2 (Fig.1), and increased soon after the increase on IA in period 3. Still, $g_{\mathrm{s}, \max }$ showed a slower recovery in period 3 than $\Psi_{\text {stem. }}$. At the end of the irrigation season of 2010 and $2011, g_{\mathrm{s}, \max }$ recovered in the 60RDI trees, but not in the 30RDI trees. Only in 2012, a year on which heavy rains were recorded from some one month before harvesting (Fig. 3c), trees of all treatments eventually showed similar $g_{\mathrm{s}, \max }$ values.

In 2010 and 2011, the 60RDI and 30RDI trees showed fruit shrivelling, leaf rolling and reductions in the angles of the leaf with the stem, all visual symptoms of severe water stress, from mid-July, i.e. from ca. 4 weeks after the end of period 2. This agrees with the periods of minimum $\Psi_{\text {stem }}$ values recorded in those trees (Fig. 4,a,b,c). In 2010, these visual symptoms were observed in the 60RDI trees until 3 weeks after the beginning of period 3. In 2011 the symptoms disappeared 1 week after the beginning of period 3. In the 30RDI trees, however, the symptoms remained all along period 3 and later, until the 
2012, visual symptoms of water stress were observed in the 60RDI trees in mid-August only, from ca. DOY 222 to DOY 234, in agreement with the significant increase on tree water stress recorded on those days (Fig. 4c). The 30RDI trees showed symptoms of water stress in 2012 from some 2 weeks after the end of period 2 (DOY 192) to some two weeks after the beginning of period 3 (DOY 254).

402

403

Crop performance

404

Trees of all treatments showed a similar LA after pruning, but differences between treatments appeared soon after the beginning of the irrigation season (Fig. 5). In 2010 and 2011 the FI trees grew all along the irrigation season. The canopies of the RDI trees, however, showed a reduced or null growth at midsummer (Fig. 5a,b), between periods 2 and 3 (Fig. 1). In 2011, the LA of the 60RDI trees increased markedly after resuming irrigation in period 3. On the three experimental years, LA of the 30RDI trees remained constant from June (2012) or July (2010 and 2011), being not affected by the increase in IA in period 3. In 2012 all the trees reached maximum LA values at the beginning of June (Fig. 5c), independently of the treatment. At the end of each irrigation season, LA was usually greater in the FI trees than in the RDI trees. Differences in LA between the 60RDI and 30RDI trees were not significant, except in the autumn of 2011, when a marked growth was observed in the 60RDI trees but not in the 30RDI trees.

The orchard was highly productive during the experimental years, and no alternate bearing was observed (Table 3). Fruit yield increased with the irrigation treatment, except in 2012, when fruit yield was greater in 60RDI than in 30RDI but the difference was not significant. For all treatments, the yearly increase in fruit yield was in accordance to that of LA. We found, in fact, a similar value of the yield of fresh fruits / LA ratio in all treatments (Table 4). The WP values for the fresh fruits increased as the irrigation supplies decreased, being more than double for the 30RDI treatment than for the FI treatment (Table 4). 424 Contrarily to the fruit yields, the VOO yields were surprisingly low, for all treatments 425 (Table 3). The percentages of VOO yield, expressed as \% of the VOO yield as compared to that of the fresh fruits, were, in fact, quite below the ca. 18\% usually reported for 'Arbequina' olives (Pastor et al., 2006a; de la Rosa et al., 2006). Values of the pulp/stone ratio were also lower than those normally reported for the Arbequina cultivar, which range 
than the RDI trees. No differences in VOO yield were found between 60RDI and 30RDI.

431 The greatest VOO yield / LA value was found in the 30RDI treatment (Table 4). As for the fruit yield, the WP values for the VOO yield also increased as IA decreased.

\section{Discussion}

435

The RDI strategy: severity of water stress

The IA supplied to the 60RDI (2959 $\mathrm{m}^{3} \mathrm{ha}^{-1}$ on average) and 30RDI trees (1366 $\mathrm{m}^{3} \mathrm{ha}^{-1}$ on average) (Table 2) must be very close to those actually consumed by the trees during the irrigation seasons, because of the low water retention capacity of the orchard soil. The greater irrigation supplies in the 60RDI treatment increased fruit yield and LA, as compared to the 30RDI treatment. No differences, however, were found in VOO yield between the two RDI treatments. This was due, at least in part, to a lower oil extractability in the 60RDI trees (data not shown), likely because of a greater fruit water content. It is known that the olive tree usually shows an inverse relationship between fruit water content and oil extractability (Gómez del Campo, 2011; Ramos and Santos, 2010). Over the three years of our study, reductions in fruit and VOO yields, as compared to FI, were $23 \%$ and $29 \%$ for $60 \mathrm{RDI}$ and $40 \%$ and $26 \%$ for 30RDI, respectively (Table 3 ). This agrees with results normally reported for olive, which show a greater impact of reduced irrigation on fresh fruit yield than on VOO yield (Lavee et al., 2007). Results for different olive cultivars for oil production, including Arbequina, are quite consistent on showing oil yield reductions of ca. 20\% with ca. 50\% DI strategies (Moriana et al., 2003; Iniesta et al., 2009; Caruso et al., 2013). It has to be taken into account, however, that the physiological and productive responses of olive trees to reduce irrigation depend on the cultivar and environmental conditions, among other factors. This was clearly illustrated by Tognetti et al. (2007; 2008) and Fernández et al. (2008) who compared the behaviour of Italian and Spanish olive cultivars under DI, from olive orchards under contrasting environmental conditions.

We found relatively constant values of fresh fruits per $\mathrm{m}^{2} \mathrm{LA}$ between treatments. This agrees with findings by Caruso et al. (2013), who found similar fruit yield efficiencies

461 based on tree size in 'Frantoio' trees under different irrigation treatments. Our values of 462 fresh fruits per $\mathrm{m}^{2}$ LA were more than double than those previously reported for 
'Arbequina' trees belonging to a SHD olive orchard in central Italy, with the same tree density than our orchard (Proietti et al., 2012). This suggests high radiation interception by the canopies and a good nutritional status of our experimental trees. The size of our trees, in fact, matched recommendations for SHD olive orchards (Tous et al., 2010), and leaf analyses showed optimum nutritional levels (Table S1). The amounts of supplied fertilizers were greater than needed (Tous et al., 2010), to avoid nutritional deficiencies during the experiments.

The WP values recorded in our orchard for fresh fruits (Table 4) were greater than those found by most authors. Correa-Tedesco et al. (2010) reported $16 \mathrm{~kg}$ of fresh fruits ha ${ }^{-}$ ${ }^{1} \mathrm{~mm}^{-1}$ in a 7-year-old 'Manzanilla fina' olive orchard in La Rioja (Argentina), with 317 trees $\mathrm{ha}^{-1}$. Fereres (2012) mentioned WP values of up to $30 \mathrm{~kg}$ of fresh fruits $\mathrm{ha}^{-1} \mathrm{~mm}^{-1}$ in 'Picual' olive orchards in areas of Spain with rainfall close to $500 \mathrm{~mm}$, as in our orchard area, and with seasonal irrigation supplies of 100-150 mm. Tognetti et al. (2007) worked in an olive orchard with 555 trees $\mathrm{ha}^{-1}$, located in a sub-humid area of central Italy. When supplying a total IA per season of ca. $100 \mathrm{~mm}$, they found WP values close to 70 and $64 \mathrm{~kg}$ of fresh fruits ha- $\mathrm{mm}^{-1}$ in 'Leccino' and 'Frantoio' trees, respectively. The fact that values of WP, both for fresh fruits and VOO, increased as the irrigation supplies decreased is expected for olive (Centritto et al., 2005; Iniesta et al., 2009; Ramos and Santos, 2010), and for other fruit tree crops. For VOO, however, our WP values were lower than those usually found in the literature. Thus, Iniesta et al. (2009) worked in a 8-10-year-old 'Arbequina' olive orchard in Córdoba (Spain) and reported 4.5-5.0 kg of olive oil ha $\mathrm{mm}^{-1}$ ${ }^{1}$ for fully irrigated trees and $13-17 \mathrm{~kg}$ of olive oil ha ${ }^{-1} \mathrm{~mm}^{-1}$ for RDI trees receiving $25 \%$ of the maximum potential ET . Tognetti et al. (2007) reported ca. 15 and $13 \mathrm{~kg}$ of olive oil ha ${ }^{-}$ ${ }^{1} \mathrm{~mm}^{-1}$ for the 'Frantoio' and 'Leccino' trees, respectively, of the experiment mentioned above, when irrigated at $66 \%$ of the maximum potential ET $_{\mathrm{c}}$. Ramos and Santos (2010), who worked in an over 80-year-old 'Cordovil' olive orchard in Alentejo (Portugal) with a very low tree density (69 trees ha ${ }^{-1}$ ), reported a WP of $2.2 \mathrm{~kg}$ of olive oil ha $\mathrm{mm}^{-1}$ for trees under SDI receiving $60 \%$ of the maximum potential $\mathrm{ET}_{\mathrm{c}}$. That value is lower but close to the WP value we found in our 60RDI trees (Table 4). We should have obtained a greater value, because of our greater tree density.

From our data of 2011 and 2012 (2010 was unusually wet, Table 2) we estimated an average $\mathrm{ET}_{\mathrm{c}}$ value in our orchard of $731 \mathrm{~mm} \mathrm{year}^{-1}$. For this $\mathrm{ET}_{\mathrm{c}}$ value, the relationships 
496 Fereres, 2012) predict $10510 \mathrm{~kg}$ fresh fruits $\mathrm{ha}^{-1}$ and $2055 \mathrm{~kg}$ olive oil ha ${ }^{-1}$. The mentioned 497 relationships were derived for olive orchards with different cultivars and tree densities 498 between ca. 350 and 500 trees $^{-1}$. For a SHD olive orchard, fresh fruit yields of up to ca. $49912 \mathrm{t} \mathrm{ha}^{-1}$ (León et al., 2007; Tous et al., 2010) or more (Pastor et al., 2006b) can be 500 expected on the $4^{\text {th }}$ to $7^{\text {th }}$ years after plantation. These results show that, while the fresh 501 fruit yields in our orchard were greater than expected, VOO yields were lower. The low 502 values of the pulp/stone ratio found in fruits of all treatments could have contributed to the 503 low VOO yields (Table 3). This aspect is analysed in the next section, since we believe it has to do with the timing of irrigation.

The aforementioned results show that, from the two tested RDI treatments, 30RDI was closer to an optimum level of irrigation reduction for achieving a sustainable balance between water saving, tree vigour and oil production. The level of irrigation reduction applied to the 30RDI trees between periods 2 and 3, i.e. in the mid-summer period of high atmospheric demand (Fig. 1), was greater than those applied by most authors. Thus, Goldhamer (1999) suggested, for 'Manzanilla' olive trees, a reduction of $25 \%$ on irrigation. Fregapane et al. (2010) worked in a 'Cornicabra' olive orchard and obtained the best results when replacing with irrigation $48 \%$ of the maximum potential $\mathrm{ET}_{\mathrm{c}}$. Motilva et

513 al. (2000), however, worked with 'Arbequina' trees and found that the best results were 514 obtained with an irrigation reduction of 75\%. Grattan et al. (2006) and Berenguer et al. 515 (2006) worked with a SHD olive orchard of similar characteristics than our orchard, 516 although in California and with SDI, and reported that oil yields were maximized over a 517 broad range of applied water, from $40 \%$ to $89 \% \mathrm{ET}_{\mathrm{c}}$, while good quality oil was obtained 518 with irrigation levels of $33 \%$ to $40 \% \mathrm{ET}_{\mathrm{c}}$. Gómez-del-Campo (2010) tested several 519 irrigation approaches, including RDI, in a 'Cornicabra' SHD olive orchard, on the first 520 three years after planting. The best results were obtained when applying significant 521 irrigation reductions from mid-August until September $30^{\text {th }}$, which amounted to over $75 \%$ 522 of IN in the last experimental year. In another experiment made in a mature SHD 523 'Arbequina' orchard, the most effective RDI strategy consisted on irrigating in July with $52430 \%$ of the water applied in a treatment on which the soil water content was maintained 525 over $-0.03 \mathrm{MPa}$ from spring until Augut $15^{\text {th }}$ and over $-0.06 \mathrm{MPa}$ from August $15^{\text {th }}$ to the end of the irrigation season (Gómez-del-Campo et al., 2011).

Our results also show that FI is not a good strategy for well-established SHD olive 528 orchards. The required IN, $\left(4701 \pm 14.7 \mathrm{~m}^{3} \mathrm{ha}^{-1}\right.$ in our case, is unaffordable in most olive 
529 growing areas, and the high levels of available soil water promotes plant vigour, as shown 530 by our LA data (Fig 5). This could be convenient on the first 3-4 years of the orchard, to reach an optimum canopy size as soon as possible. Once the orchard is established,

532 however, excessive vigour will cause difficulties on keeping a suitable tree size (Connor 533 2006; León et al., 2007). In addition, FI could reduce oil quality, as compared to a DI 534 strategy (Tovar et al., 2002; d'Andria et al., 2004; Servili et al., 2007).

The RDI strategy: timing of water stress

538 The high crop performance of the RDI trees, despite the significant reduction on the irrigation supplies, shows that the timing for irrigation adjustment depicted in Fig. 1 was quite in accordance with the sensitivity of the olive tree to water stress. Still, recent findings on the effect of water stress on olive fruit development suggest possible improvements for our RDI strategy. Thus, Hammami et al. (2011), among others, reported that the beginning of olive fruit development is characterized by active cell division, a quick increase of the endocarp area and a slow but increasing growth of the mesocarp area. They observed, in six olive cultivars, that the endocarp size was strongly correlated with fruit size, and that the fruit size was mainly due to cell number, and not to cell size. All cultivars showed that some two thirds of the final cell number was produced in the first 8 weeks AFB. These findings show that excessive water stress in the first 8 weeks AFB may reduce cell number in olive fruits. This suggests that irrigating between periods 1 and 2, in case the rainfall supplies are far from replacing the crop water needs, could be necessary to avoid limiting the final fruit size.

The low pulp/stone ratios observed in our orchards (Table 3) could have been due, in fact, to excessive water stress in our experimental trees between periods 1 and 2. As

554 shown in Figs. 1 and 3, no irrigation was made between those two periods. Rainfall amounts collected in the orchard in May were $12.8 \mathrm{~mm}$ in 2010, $4.7 \mathrm{~mm}$ in 2011 and 7.6 $\mathrm{mm}$ in 2012. These low water supplies, together with the low water holding capacity of the soil (Fig. S1) could have caused severe tree water stress between periods 1 and 2, which could have had a negative impact on fruit development. This includes cell number, which cannot recover even if enough water is supplied later on the year. It is known, in fact, that predawn leaf water potential values between -2 MPa (Costagli et al., 2003) and -3 MPa 
562 in olive fruits. Stress levels within that range can be easily achieved in our experimental 563 orchard (Fernández et al., 2011). We, however, did not measure the development of the 564 different fruit tissues along our irrigation seasons, and have no information on the IA 565 required between periods 1 and 2 to avoid a negative impact on fruit cell number and cell 566 size. We can speculate that a total IA between period 1 and 2 of $20 \%$ IN, which amounts to $567238 \mathrm{~m}^{3} \mathrm{ha}^{-1}$ would avoid those effects, but this is still to be tested.

568 Another possible improvement of our RDI strategy is related to the irrigation 569 supplies in period 3. Our results on $\Psi_{\text {stem }}$ and $g_{\text {s, max }}$, and the fact that visual symptoms of 570 water stress were still observed in the 30RDI trees during period 3 over the experimental 571 years, show that IA on period 3 was not enough for the 30RDI trees to fully recover from 572 water stress. A greater increase on IA on this period could be profitable, since the olive tree 573 shows an outstanding capacity to produce new assimilates for fruit growth after 574 midsummer, provided enough water in the soil is available on that phase of the crop cycle 575 (Lavee and Wodner, 1991; Moriana et al., 2003). Our records shows that the difference 576 between the average IA actually applied to the 30RDI trees on period 3 and that required to replacing IN on that period amounts to $480 \mathrm{~m}^{3} \mathrm{ha}^{-1}$. The two calculated amounts for the supposedly improved RDI strategy, added to the average IA supplied to the 30RDI trees over the three experimental years $\left(1366 \mathrm{~m}^{3} \mathrm{ha}^{-1}\right)$ yields a total IA of $2084 \mathrm{~m}^{3} \mathrm{ha}^{-1}$, i.e. $44 \%$

580 of the average IN calculated for the FI treatment over the three experimental years. But 581 both the amount and frequency of irrigation between periods 1 and 2 and the overall effect 582 of the supposedly improved RDI strategy on crop performance remains to be tested in 583 future experiments.

\section{Conclusions}

587 From the three tested irrigation treatments, 30RDI was the closest to an optimum irrigation 588 management for oil production in our orchard. It required a total IA of $1366 \mathrm{~m}^{3} \mathrm{ha}^{-1}$, which 589 meant $29 \%$ of IN. It led both to high WP values and reduced tree vigour, which is positive 590 for keeping a suitable tree size for mechanical harvesters and for getting enough radiation 591 interception at the base of the canopies. Our results, therefore, show that the 30RDI 592 treatment is appropriate for a sustainable irrigation management in SHD olive orchards of 593 similar characteristics than our olive orchard. Still, our results, together with recent 594 findings on the effect of water stress on olive fruit development, allowed us to suggest 
possible improvements on the RDI strategy, based on IA increases both between periods 1 and 2 and on period 3. As a total, this supposedly improved RDI strategy would require a total IA of ca. $2100 \mathrm{~m}^{3} \mathrm{ha}^{-1}$. However, both the amount and frequency of irrigation between periods 1 and 2 and the overall effect of the suggested RDI strategy on crop performance are still to be tested.

600

Acknowledgements This work was funded by the Spanish Ministry of Science and innovation (research project AGL2009-11310/AGR), by the Junta de Andalucía (research project AGR-6456-2010) and by the FEDER programme. C.M. R-D, J.M. T-R and S. E-F benefited from a FPDI research fellowship from the Junta de Andalucia, a FPI grant from the Spanish Ministry of Science and Innovation, and a JAE-predoc fellowship of the CSIC, respectively. Antonio Montero helped us with the field and laboratory work. Thanks to the owners of Internacional Olivarera, S.A.U. (Interoliva), for allowing us to make the experiments in the Sanabria orchard. We also thank Silvia Seller, agronomist, and Juan

610

\section{References}

612

Alegre S, Marsal J, Mata M, Arbonés A, Girona J (2002) Regulated deficit irrigation in olive tres (Olea europea L., cv 'Arbequina') for oil production. Acta Hortic 586:259262

Allen RG, Pereira LS, Raes D, Smith M (1998) Crop evapotranspiration. Guidelines for computing crop water requirements. Irrigation and drainage paper 56. FAO, Rome, Italy

Ben-Gal A, Kool D, Agam N, van Halsema GE, Yermiyahu U, Yafe A, Presnov E, Erel R, Majdop A, Zipori I, Segal E, Rüger S, Zimmermann U, Cohen Y, Alchanatis V, Dag A (2010) Whole-tree water balance and indicators for short-term drought stress in non-bearing 'Barnea' olives. Agric Water Manage 98:124-133

Berenguer MJ, Vossen PM, Grattan SR, Connell JH, Polito VS (2006) Tree irrigation

626 Beutel J, Uriu K, Lilleland O (1983) Leaf analysis for California deciduous fruits. In: Soil 627 and plant tissue testing in California. University of California, Bull. 1879. 
628 Caruso G, Rapoport HF, Gucci R (2013) Long-term evaluation of yield components of young olive trees during the onset of fruit production under different irrigation regimes. Irrig Sci 31:37-47

Centritto M, Wahbi S, Serraj R, Chaves MM (2005) Effects of partial rootzone drying (PRD) on adult olive tree (Olea europaea) in field conditions under arid climate. II. Photosynthetic responses. Agric Ecosys Environ 106:303-311

Chalmers DJ, Mitchell PD, van Heek L (1981) Control of peach tree growth and 635 productivity by regulated water supply, tree density and summer pruning. J Am Soc Hortic Sci 106:307-312

Chapman HD (Ed.) (1966) Diagnostic criteria for plants and soils. University of California, Div. of Agric. Science, 793 pp. Berkeley, California

Childers NF (Ed.) (1966) Fruit nutrition. Horticultural publications, 888 pp. New Jersey

Connor DJ (2006) Towards optimal designs for hedgerow olive orchards. Aus J Agric Res 57:1067-1072Correa-Tedesco G, Rousseaux MC, Searles PS (2010) Plant growth and yield responses in olive (Olea europaea) to different irrigation levels in an arid region of Argentina. Agric Water Manage 97:1829-1837

Costagli G, Gucci R, Rapoport H (2003) Growth and development of fruits of olive 'Frantoio' under irrigated and rainfed conditions. J Hortic Sci Biotech 78:119-124

Cuevas MV, Martín-Palomo MJ, Díaz-Espejo A, Torres-Ruiz JM, Rodriguez-Dominguez

Dabbou S, Dabbou S, Chehab H, Brahmi F, Taticchi A, Servili M, Hammami M 2011 CM, Perez-Martin A, Pino-Mejías R, Fernández JE (2012) Assessing water stress in a

d'Andria R, Lavini A, Morelli G, Patumi M, Terenziani S, Calandrelli D, Fragnito F (2004) Effect of water regimes on five picking and double aptitude olive cultivars (Olea europaea L.). J Hort Sci Biotechnol. 78(1):15-23

De la Rosa R, León L, Guerrero N, Barranco D, Rallo L (2006) Resultados preliminares de un ensayo de densidades de plantación en olivar en seto. Olivicultura 160:43-46 
661

662

663

664

665

666

667

668

669

670

671

672

673

674

675

676

677

678

679

680

681

682

683

684

685

686

687

688

689

690

691

Casal A, Torres-Ruiz JM, Fernández JE (2012) Steps toward an improvement in process-based models of water use by fruit trees: A case study in olive. Agric Water Manage 114: 37-49

Diaz-Espejo A, Walcroft AS, Fernandez JE, Hafidi B, Palomo MJ, Giron IF (2006) Modeling photosynthesis in olive leaves under drought conditions. Tree Physiol 26:1445-1456

Dichio B, Xiloyannis C, Angelopoulos K, Nuzzo V, Bufo SA, Celano G (2003) Droughtinduced variations of water relations parameters in Olea europea. Plant Soil 257:381389

Fereres E (2012) (Ed.) Fruit trees ans vines. Section 4.1 Olive. In: Crop Yield response to Water. Steduto P, Hsiao TC, Fereres E, Raes D, Eds. Irrigation and Drainage Paper No. 66, Food and Agriculture Organisation of the United Nations, Rome. Pp. 298-313

Fereres E, Evans RG (2006) Irrigation of fruit trees and vines: an introduction. Irrig Sci $24: 55-57$

Fereres E, Soriano MA (2007) Deficit irrigation for reducing agricultural water use. J Exp Bot 58:147-159.

Fernández JE, Diaz-Espejo A, d'Andria R, Sebastiani L, Tognetti R (2008) Potential and limitations of improving olive orchard design and management through modelling. Plant Biosys 142(1):130-137

Fernández JE, Moreno F, Girón IF, Blázquez OM (1997) Stomatal control of water use in olive tree leaves. Plant Soil 190:179-192

Fernández JE, Moreno F, Martín-Palomo MJ, Cuevas MV, Torres-Ruiz JM, Moriana A (2011) Combining sap flow and trunk diameter measurements to assess water needs in mature olive orchards. Environ Exp Bot 72:330-338

Fernández-Escobar R (2001) Fertilización. In: Barranco D, Fernández-Escobar R, Rallo L (Eds.) El Cultivo del Olivo, Mundi Prensa, Madrid, pp. 255-284

Fregapane G, Gómez-Rico A, Salvador MD (2010) Influence of Irrigation Management and Ripening on Virgin Olive Oil Quality and Composition. In: Olives and Olive Oil in Health and Disease Prevention. Preedy VR Ed. Elsevier, chapter 6, pp. 51-58

Goldhamer DA (1999) Regulated deficit irrigation for California canning olives. Acta Hort 474:369-372 
692 Goldhamer DA, Viveros M, Salinas M (2006) Regulated deficit irrigation in almonds:

693 effects of variation in applied water and stress timing on yield and yield components.

694 Irrig Sci 24:101-114.

695 Gómez-del-Campo M (2007) Effect of water supply on leaf area development, stomatal 696 activity, transpiration, and dry matter production and distribution in young olive trees. 697 Aus J Agric Res 58:385-391.

698 Gómez-del-Campo M (2010) Physiological and growth responses to irrigation of a newly 699

Gómez-del-Campo M (2011) Summer deficit-irrigation strategies in a hedgerow olive

Grattan SR, Berenguer MJ, Connell JH, Polito VS, Vossen PM (2006) Olive oil production as influenced by different quantities of applied water. Agric Water Manage 85:133140

Greven M, Neal S, Green S, Dichio B, Clothier B (2009). The effects of drought on the water use, fruit development and oil yield from young olive trees. Agric Water Manage 96:1525-1531

Gucci R, Caruso G, Bertolla C, Urbani S, Taticchi A, Esposto S, Servili M, Sifola MI, Pellegrini S, Pagliai M, Vignozzi N (2012) Changes of soil properties and tree performace induced by soil management in a high-density olive orchard. Eur J Agron $41: 18-27$

Gucci R, Lodolini EM, Rapoport HF (2009) Water deficit-induced changes in mesocarp cellular processes and the relationship between mesocarp and endocarp during olive fruit development. Tree Physiol 29:1575-1585

Hammami SBM, Manrique T, Rapoport HF (2011) Cultivar-based fruit size in olive depends on different tissue and cellular processes throughout growth. Sci Hort $130: 445-451$

Iniesta F, Testi L, Orgaz F, Villalobos FJ (2009) The effects of regulated and continuous deficit irrigation on the water use, growth and yield of olive trees. Eur J Agron 30: $258-265$

Kijne JW, Barker R, Molden DJ (2003) Water Productivity in Agriculture: Limits and Opportunities for Improvement. CABI, IWMI, Wallingford, UK 
Lavee S, Hanoch E, Wodner M, Abramowich H (2007) The effect of predetermined deficit irrigation on the performance of cv. Muhasan olives (Olea europaea L.) in the eastern coastal plain of Israel. Sci Hort 112:156-163

Lavee S, Nashef M, Wodner M, Harshemesh H (1990) The effect of complementary irrigation added to old olive trees (Olea europaea L.) cv. Souri on fruit characteristics, yield and oil production. Adv Hort Sci 4:135-138

Lavee S, Wodner M (1991) Factors affecting the nature of oil accumulation in fruit of olive (Olea europaea L.) cultivars. J Hort Sci 66(5):583-591

León L, de la Rosa R, Rallo L, Guerrero N, Barranco D (2007) Influence of spacing on the initial production of hedgerow 'Arbequina' olive orchards. Span J Agric Res 5:554558

Martínez JM, Muñoz E, Alba J, Lanzón A (1975) Informe sobre utilización del analizador de rendimientos "Abencor". Report about the use of the "Abencor" analyzer. Grasas y Aceite 26:379-385

Morettini A (1972) Olivicoltura, 2nd edn. Ramo Editoriale Degli Agricoltori (REDA) Press, Rome

Moriana A, Fereres E (2002) Plant indicators for scheduling irrigation of young olive trees. Irrig Sci 21:83-90

Moriana A., Orgaz F., Pastor M., and Fereres E (2003) Yield responses of a mature olive orchard to water deficits. J Am Soc Hort Sci 128:425-431

Moriana A, Pérez-López D, Gómez-Rico A, Salvador MD, Olmedilla N, Ribas F, Fregapane G (2007) Irrigation scheduling for traditional, low-density olive orchards: Water relations and influence on oil characteristics. Agric Water Manage 87:171-179

Moriana A, Pérez-López D, Prieto MH, Ramírez-Santa-Pau M, Pérez-Rodriguez JM (2012) Midday stem water potential as a useful tool for estimating irrigation requirements in olive trees. Agric Water Manage 112:43-54

Motilva MJ, Tovar MJ, Romero MP, Alegre S, Girona J (2000) Influence of regulated deficit irrigation strategies applied to olive trees (Arbequina cultivar) on oil yield and oil composition during the fruit ripening period. J Sci Food Agric 80(14):2037-2043

Orgaz F, Fereres E (2001) Riego. In: Barranco D, Fernández-Escobar R, Rallo L (Eds.). E1 Cultivo del Olivo, 4th Edition. Coedition Mundi-Prensa and Junta de Andalucía, Madrid, pp. 285-306 
Pastor M, García-Vila M, Soriano MA, Vega V, Fereres E (2007) Productivity of olive orchards in response to tree density. J Hortic Sci Biotechnol 82(4):555-562

Pastor M, Hidalgo J, Vega V (2006a) Densidades de plantación en olivar de regadío. Agricultura 888:708-718

Pastor M, Hidalgo J, Vega V, Fereres E (2006b) Viabilidad agronómica y económica de las plantaciones superintensivas en Andalucía. Vida Rural 238:60-66

Patumi M, d'Andria R, Marsilio V, Fontanazza G, Morelli G, Lanza B (2002) Olive and olive oil quality after intensive monocone olive growing (Olea europaea L., cv. Kalamata) in different irrigation regimes. Food Chem 77:27-34

Pinheiro J, Bates D, DebRoy S, Sarkar D, Team RDC (2011) nlme: Linear and Nonlinear Mixed Effects Models. R package version 3.1-102. Vienna: R Foundation for Statistical Computing

Proietti P, Nasini L, Ilarioni L (2012) Photosynthetic behavior of Spanish Arbequina and Italian Maurino olive (Olea europaea L.) cultivars under super-intensive grove conditions. Photosynthetica 50(2):239-246

Rallo L (1995) Selección y mejora genética del olivo en España. Olivae 59(12):46-53

Rallo L, Rapoport HF (2001) Early growth and development of the olive fruit mesocarp. J Hort Sci Biotechnol 76:408-412

Ramos AF, Santos FL (2009) Water use, transpiration, and crop coefficients for olives (cv. Cordovil), grown in orchards in Southern Portugal. Biosys Eng 102:321-333

Ramos AF, Santos FL (2010) Yield and olive oil characteristics of a low-density orchard (cv. Cordovil) subjected to different irrigation regimes. Agric Water Manage 97:363373

Rapoport HF, Costagli G, Gucci R (2004) The effect of water deficit during early fruit development on olive fruit morphogenesis. J Am Soc Hort Sci 129:121-127

Rapoport HF, Hammami SBM, Martins P, Pérez-Priego O, Orgaz F (2012) Influence of water deficits at different times during olive tree inflorescence and flower development. Environ Exp Bot 77:227-233

Rapoport HF, Rallo L (1991) Post-anthesis flower and fruit abscission in 'Manzanillo' olive. J Am Soc Hort Sci 116:720-723

Rius X, Lacarte JM (2010) La revolución del olivar. El cultivo en seto, 340 pp

Rodriguez-Dominguez CM, Ehrenberger W, Sann C, Rüger S, Sukhorukov V, MartínPalomo MJ, Diaz-Espejo A, Cuevas MV, Torres-Ruiz JM, Perez-Martin A, 

and leaf turgor pressure in olive trees using the leaf patch pressure probe. AgricWater Manage 114:50-58

Schwabe WW, Lionakis SM (1996) Leaf attitude in olive relation to drought resistance. J Hortic Sci 71(1):157-166

Servili M, Esposto S, Lodolini E, Selvaggini R, Taticchi A, Urbani S, Montedoro GF, Serravalle M, Gucci R (2007) Irrigation effects on quality, phenolic composition, and selected volatiles of virgin olive oils cv. Leccino. J Agric Food Chem 55:6609-6618

Testi L, Villalobos FJ, Orgaz F, Fereres E (2006) Water requirements of olive orchards: I simulation of daily evapotranspiration for scenario analysis. Irrig Sci 24:69-76

800

801

802

803

804

Tognetti R, d'Andria R, Lavini A, Morelli G (2006) The effect of deficit irrigation on crop yield and vegetative development of Olea europaea L. (cvs. Frantoio and Leccino). Eur J Agron 25:356-364

Tognetti R, d'Andria R, Morelli G, Alvino A (2005) The effect of deficit irrigation on seasonal variations of plant water use in Olea europaea L. Plant Soil 273(1-2):139155

806

Tognetti R, d'Andria R, Sacchi R, Lavini A, Morelli G Alvino A (2007) Deficit irrigation affects seasonal changes in leaf physiology and oil quality of Olea europaea (cultivars Frantoio and Leccino). Ann Appl Biol 150:169-186

Tognetti R, Giovanelli A, Lavini A, Morelli G, fragnito F, d'Andria R (2009) Assessing environmental controls over conductances through the soil-plant-atmosphere continuum in an experimental olive tree plantation of southern Italy. Agric For Meteorol 149:1229-1243

Tognetti R, Morales-Sillero A, d'Andria R, Fernández JE, Lavini A, Sebastiani L,

Tous J, Romero A, Plana J (1998) Comportamiento agronómico y comercial de cinco variedades de olivo en Tarragona. Invest Agr: Prod Prot Veg 13(1-2):97-109

819 Tovar MJ, Romero MP, Alegre S, Girona J, Motilva MJ (2002) Composition of 820 organoleptic characteristics of oil from Arbequina olive (Olea europaea L.) trees under deficit irrigation. J Sci Food Agric 82:1755-1763 
822 Troncoso A, Cantos M, Liñán J, Fernández JE (2001) Fertirrigación. In: Barranco D, 823 Fernández-Escobar R, Rallo L (Eds.). El Cultivo del Olivo, 4th Edition. Coedition 824 Mundi-Prensa and Junta de Andalucía, Madrid, pp. 307-332

825 USDA (2010) Keys to Soil Taxonomy (11th Edition). United States Department of 826 Agriculture, Natural Resource Conservation Service, 334 pp

827 Vossen PM, Connell JH, Klonsky KM, Livingston P (2004) Sample Costs to Establish a 828 Super-High Density Olive Orchard and Productive Olive Oil - Sacramento Valley. 829 University of California, Cooperative Extension. Department of Agricultural and $830 \quad$ Resource Economics. Davis, CA 
832 Fig. 1 Regulated deficit irrigation strategy applied in the experimental orchard for the 833 60RDI treatment. The figure shows the three periods at which we considered the olive tree 834 is most sensitive to water stress. The 30RDI strategy was similar, but in periods 2 and 3 the 835 irrigation supplies amounted to $60 \%$ and $30 \%$ of the irrigation needs (IN) only. Also, 836 between period 1 and period 2 the 30RDI trees were irrigated with $10 \%$ of IN. Other 837 details, including the frequency of irrigation, are given in the Materials and methods 838 section. See The Discussion Section for possible improvements of the irrigation strategy. 839 Dates for the different phenological stages may change depending on the year, location, 840 cultivar and management practices, among other factors. The dates shown in the figure 841 correspond to our orchard on the three experimental years. The depicted curves of shoot 842 growth, fruit growth and oil accumulation are typical curves for olive trees growing under 843 non limiting soil water conditions. The shape of these curves may change under different 844 soil and atmospheric water conditions, among other factors. The shown harvesting date 845 agrees with those in the three experimental seasons. $\mathrm{ET}_{\mathrm{c}}=$ crop evapotranspiration; $P_{\mathrm{e}}=$ 846 effective precipitation; AW = available water in the soil; w. AFB = weeks after full bloom

848 Fig. 2 Time courses, for the three irrigation seasons, of the FAO56 Penman-Monteith 849 potential evapotranspiration $\left(\mathrm{ET}_{\mathrm{o}}\right)$ collected from a nearby standard weather station 850 belonging to the Agroclimatic Information Network of the Junta of Andalusia (A). Also 851 shown are the seasonal courses of solar global radiation, $R_{\mathrm{s}}(\mathrm{B})$ and maximum $\left(T_{\mathrm{a}, \max }\right)$ and 852 minimum $\left(T_{\mathrm{a}, \mathrm{min}}\right)$ air temperature recorded by the weather station in the orchard $(\mathrm{C})$. The 853 lines represent the average values for the three irrigation seasons, 2010 to 2012. The points represent the maximum and minimum values. DOY $=$ day of year

856 Fig. 3 Seasonal courses both of the irrigation amount (IA) supplied to the each treatment 857 and precipitation $(P)$ collected in the orchard (A,B,C). The seasonal courses of the relative 858 extractable water (REW) derived from the soil water contents measured in the plots of each 859 treatment are also shown (D,E,F). Different letters indicate significant differences between 860 treatments, at $p<0.05$. Letters are not shown when no differences were found. REW 861 values for the FI treatment in 2010 were not considered in the statistical analysis because 862 they correspond to one plot only. DOY = day of year 
865 Fig. 4 Seasonal courses of midday stem water potential, $\Psi_{\text {stem }}$ (A, B, C), and maximum 866 stomatal conductance, $g_{\mathrm{s}, \max }(\mathrm{D}, \mathrm{E}, \mathrm{F})$, measured during the irrigation periods of the three 867 experimental years in representative trees of each treatment. Each point represents the 868 average of eight leaf measurements per treatment. The error bars represent \pm the standard 869 error. Different letters indicate significant differences between treatments at $p<0.05$. 870 Letters are not shown when no differences were found. Values for the FI treatment in 2010 871 were not considered in the statistical analysis because they correspond to one plot only. 872 DOY $=$ day of year

874 Fig. 5 Seasonal courses of leaf area (LA, $n=4)$ for each irrigation treatment and season. 875 Vertical bars represent \pm the standard errors. Different letters indicate significant 876 differences between treatments at $p<0.05$. Letters are not shown when no differences 877 were found. Values for the FI treatment in 2010 were not considered in the statistical 878 analysis because they correspond to one plot only. DOY = day of year

879

880 
884 Table S1 Concentrations of main nutrients in leaves from trees under the three studied 885 water treatments. These results correspond to the leaf samples taken in July 2012. Results 886 from the 2010 and 2011 analyses also showed all the values to be within the optimum 887 levels range.

888

889 Fig. S1 Time courses of the amount of water in the soil close to a dripper of a 60RDI and 890 a 30RDI tree. The top graph shows data between two rainfall events recorded in early 891 March, a period of low atmospheric demand (average $\mathrm{ET}_{\mathrm{o}}$ for the shown period $=3.3 \mathrm{~mm}$ ) 892 (A). The bottom graph shows data for irrigation events occurring on late July, the period of 893 the year with the greatest atmospheric demand (average $\mathrm{ET}_{\mathrm{o}}$ for the shown period $=8.2$ $894 \mathrm{~mm}$ ) (B). The dashed line shows the readily available water in the orchard soil 895 
Table 1. Values of main physical and chemical variables determined from soil samples taken in the orchard in March 2010. The shown values are average values of six locations randomly chosen in the 0.346 ha covered by the experimental plots. The soil samples were taken from the top 0.0-0.6 m soil layer.

\begin{tabular}{|c|c|c|c|}
\hline Variable (unit) & value & Variable (unit) & value \\
\hline Coarse sand (\%) & 66.4 & $\mathrm{C} / \mathrm{N}$ & 6.79 \\
\hline Fine sand $(\%)$ & 11.3 & O. organic matter (\%) & 0.28 \\
\hline Silt $(\%)$ & 2.2 & O. organic carbon (\%) & 0.16 \\
\hline Clay $(\%)$ & 20.1 & Organic N (\%) & 0.025 \\
\hline$\rho\left(\mathrm{Mg} \mathrm{m}^{-3}\right)$ & 1.73 & Kjeldahl-N (\%) & 0.044 \\
\hline$\theta_{\mathrm{v}}\left(\mathrm{m}^{3} \mathrm{~m}^{-3}\right)$ at $\Psi_{\mathrm{m}}=-0.03 \mathrm{MPa}$ & 0.18 & Available $\mathrm{P}\left(\mathrm{mg} \mathrm{kg}^{-1}\right)$ & 2.95 \\
\hline$\theta_{\mathrm{v}}\left(\mathrm{m}^{3} \mathrm{~m}^{-3}\right)$ at $\Psi_{\mathrm{m}}=-2.50 \mathrm{MPa}$ & 0.07 & Available $\mathrm{K}\left(\mathrm{mg} \mathrm{kg}_{-1}\right)$ & 90 \\
\hline$K_{\text {sat }}\left(\mathrm{cm} \mathrm{day}^{-1}\right)$ & 40.7 & Available $\mathrm{Ca}\left(\mathrm{mg} \mathrm{kg}^{-1}\right)$ & 1885 \\
\hline $\mathrm{EC}_{\mathrm{e}}\left(\mathrm{mS} \mathrm{m}^{-1}\right)$ & 25 & Available $\mathrm{Mg}\left(\mathrm{mg} \mathrm{kg}^{-1}\right)$ & 394 \\
\hline $\mathrm{pH}$ & 6.34 & & \\
\hline
\end{tabular}

$\rho=$ dry bulk soil density; $Q_{\mathrm{v}}=$ volumetric soil water content; $\Psi_{\mathrm{m}}=$ soil matric potential; $K_{\text {sat }}=$ hydraulic conductivity in the range near saturation; $\mathrm{EC}_{e}=; \mathrm{C} / \mathrm{N}=$ Carbon/Nitrogen ratio; $\mathrm{O}$. = oxidizable. 


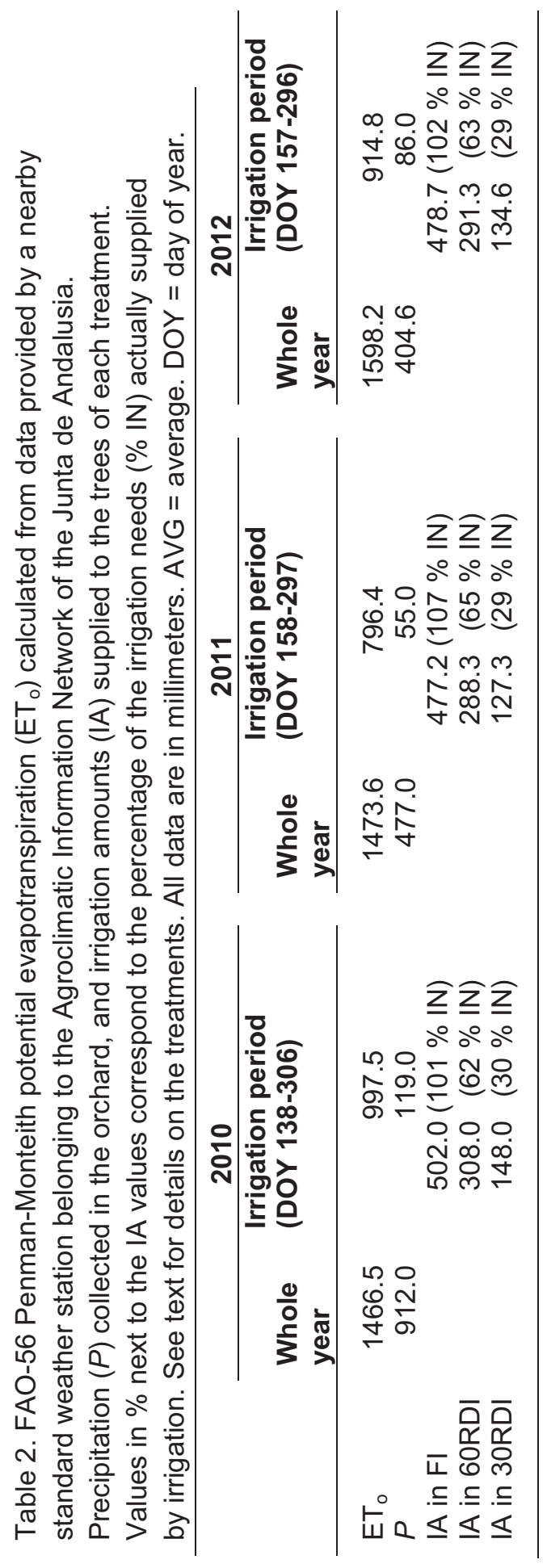


Table 3. Fruit and virgin olive oil (VOO) yields, and pulp/stone ratio for each year and treatment. Values between brackets refer to the VOO yield expressed as percentage of the fresh fruits weight. Different letters indicate significant differences between treatments at $p<0.05$. Values of the $\mathrm{FI}$ treatment in $\mathbf{2 0 1 0}$ were not considered in the statistical analyses, because of the lack of replications.

\begin{tabular}{|c|c|c|c|c|}
\hline Year & Treatment & Fruit yield $\left(\mathrm{kg} \mathrm{ha}^{-1}\right)$ & VOO yield $\left(\mathrm{kg} \mathrm{ha}^{-1}\right)$ & Pulp/stone ratio \\
\hline \multirow[t]{3}{*}{2010} & $\mathrm{FI}$ & 15606.9 & $998.4(6.4 \%)$ & 3.3 \\
\hline & 60RDI & $12678.6 \mathrm{~b}$ & $913.3(7.2 \%) \mathrm{a}$ & $3.2 \mathrm{~b}$ \\
\hline & 30RDI & 9183.5 a & $867.3(9.4 \%) a$ & $2.3 \mathrm{a}$ \\
\hline \multirow[t]{3}{*}{2011} & $\mathrm{FI}$ & $19760.8 \mathrm{c}$ & $1270.0(6.4 \%) b$ & $3.5 \mathrm{c}$ \\
\hline & 60RDI & $14477.4 \mathrm{~b}$ & $860.4(5.8 \%) a$ & $2.9 \mathrm{~b}$ \\
\hline & 30RDI & $9729.4 \mathrm{a}$ & $931.4(9.8 \%) \mathrm{a}$ & $2.4 \mathrm{a}$ \\
\hline \multirow[t]{3}{*}{2012} & $\mathrm{FI}$ & $23612.1 \mathrm{~b}$ & $1291.6(5.4 \%) b$ & $4.2 \mathrm{~b}$ \\
\hline & 60RDI & $18275.8 \mathrm{a}$ & $740.2(4.0 \%) \mathrm{a}$ & $4.0 \mathrm{~b}$ \\
\hline & 30RDI & $16227.0 \mathrm{a}$ & $828.3(5.1 \%) a$ & $3.0 \mathrm{a}$ \\
\hline
\end{tabular}


Table 4. Yield of fresh fruits and virgin olive oil (VOO) per unit of leaf area (LA), and water productivity in terms of fresh fruit and VOO, for each irrigation treatment. Data are the average \pm standard deviation of the three experimental years.

\begin{tabular}{|c|c|c|c|c|}
\hline \multirow[b]{2}{*}{ Treatments } & \multicolumn{2}{|c|}{$\begin{array}{l}\text { Yield / LA } \\
\left(\mathrm{kg} \mathrm{m}^{-2}\right)\end{array}$} & \multicolumn{2}{|c|}{$\begin{array}{l}\text { Water productivity } \\
\left(\mathrm{kg} \mathrm{ha}^{-1} \mathrm{~mm}^{-1}\right)\end{array}$} \\
\hline & Fresh fruits & voo & Fresh fruits & voo \\
\hline $\mathrm{FI}$ & $1.104 \pm 0.024$ & $0.067 \pm 0.005$ & $40.61 \pm 9.14$ & $2.45 \pm 0.40$ \\
\hline 60RDI & $1.181 \pm 0.236$ & $0.066 \pm 0.178$ & $51.37 \pm 10.83$ & $2.83 \pm 0.25$ \\
\hline 30RDI & $1.088 \pm 0.237$ & $0.084 \pm 0.020$ & $86.34 \pm 30.49$ & $6.44 \pm 0.77$ \\
\hline
\end{tabular}




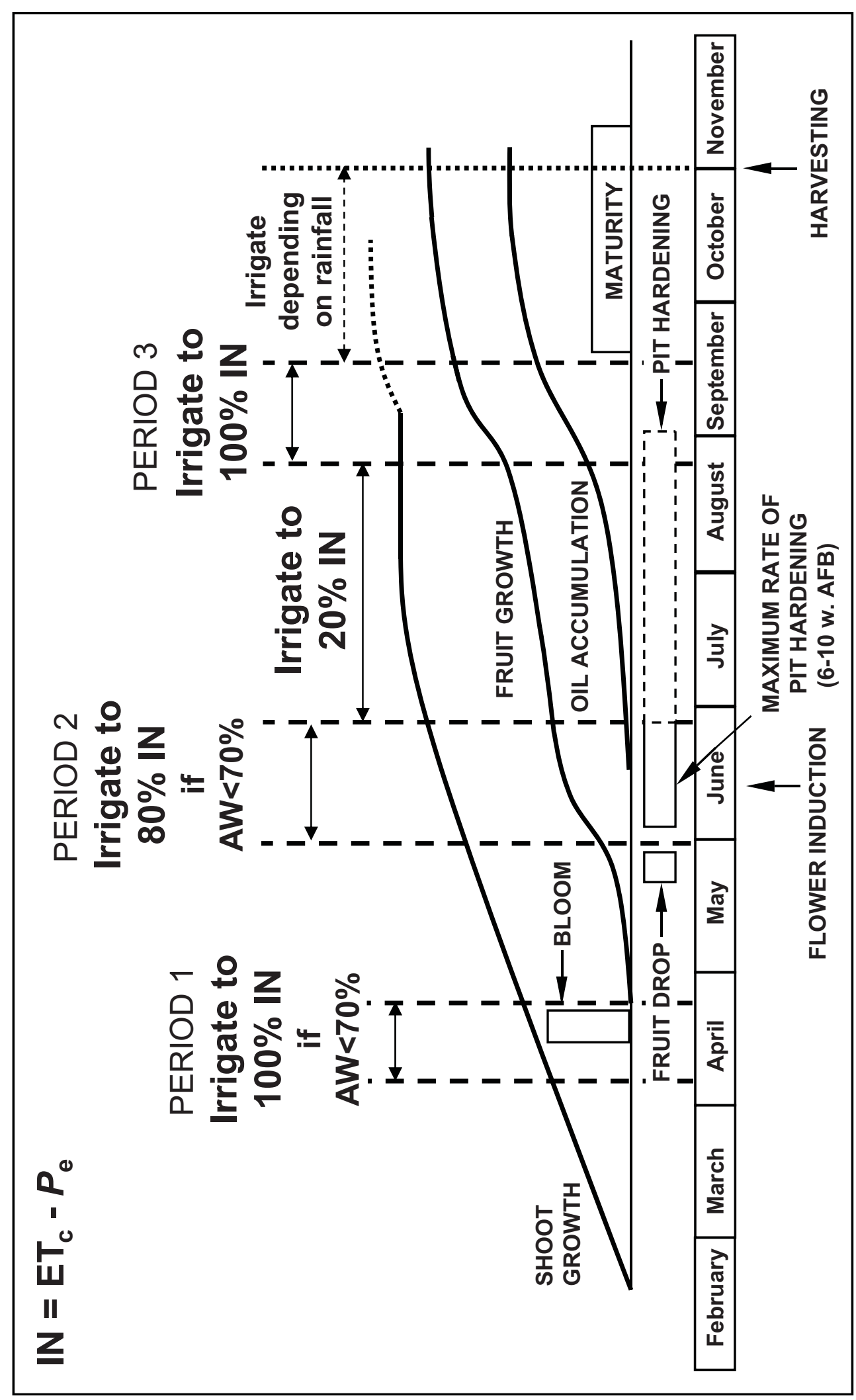




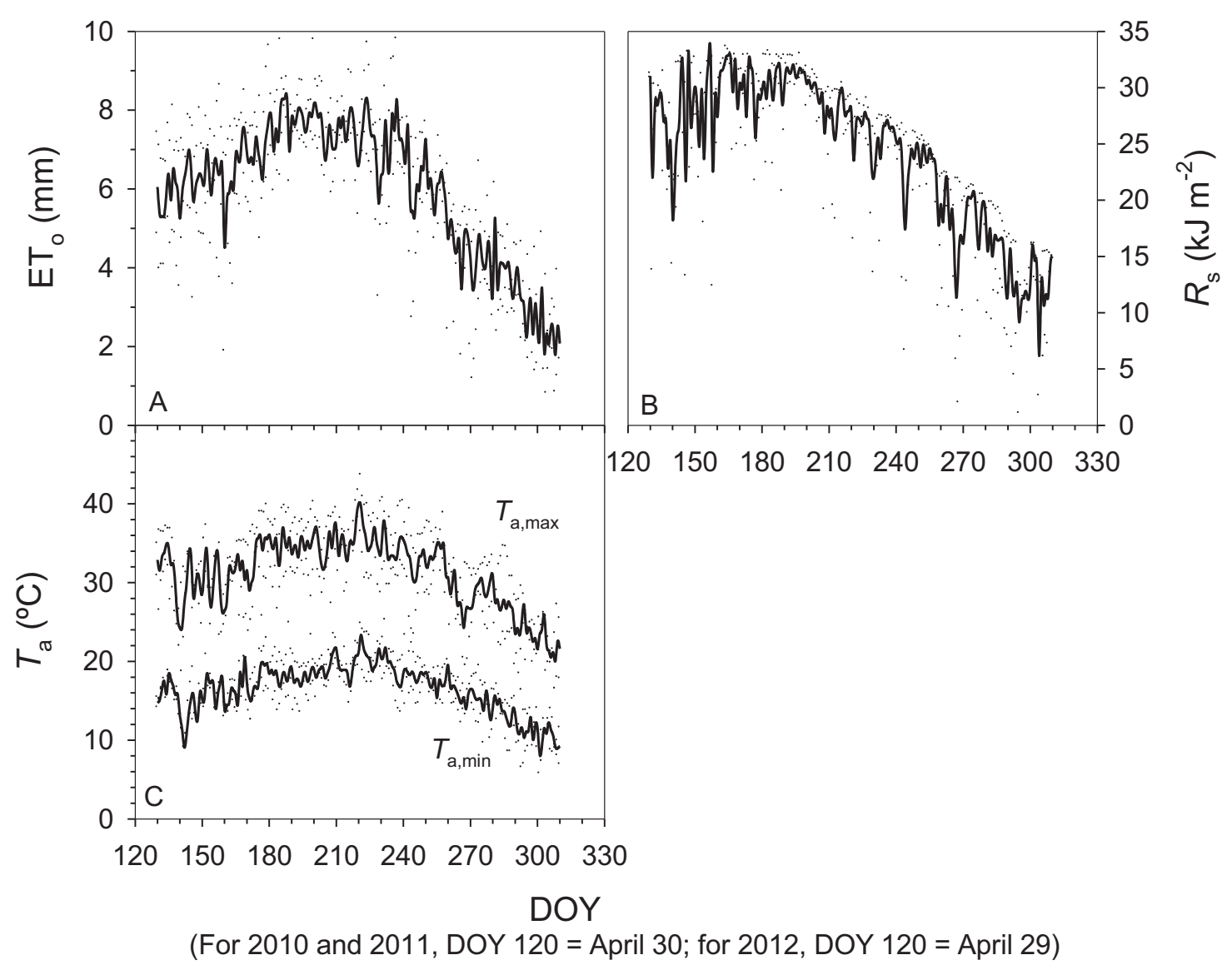




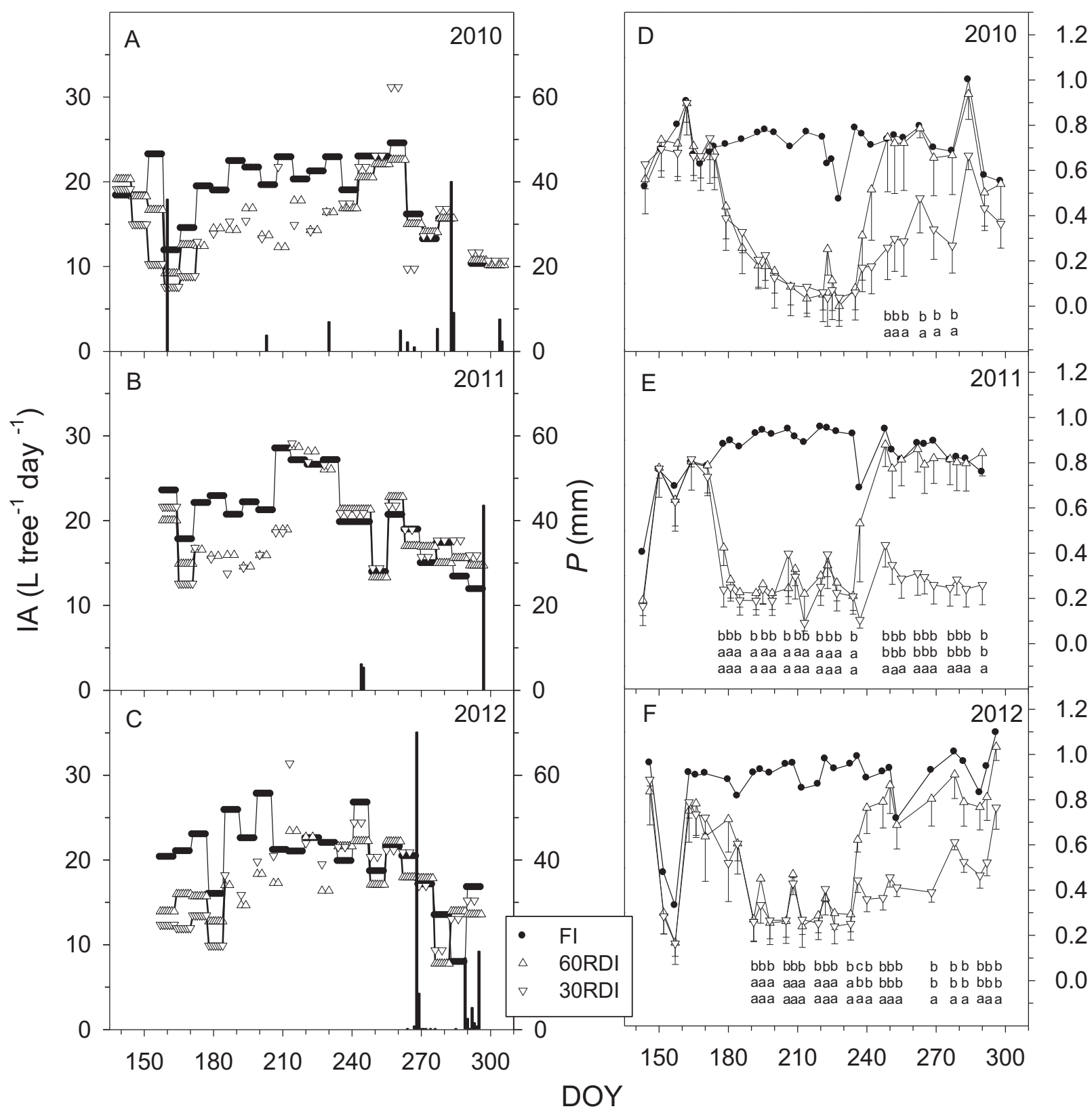

(For 2010 and 2011, DOY 150 = May 30; for 2012, DOY $150=$ May 29) 


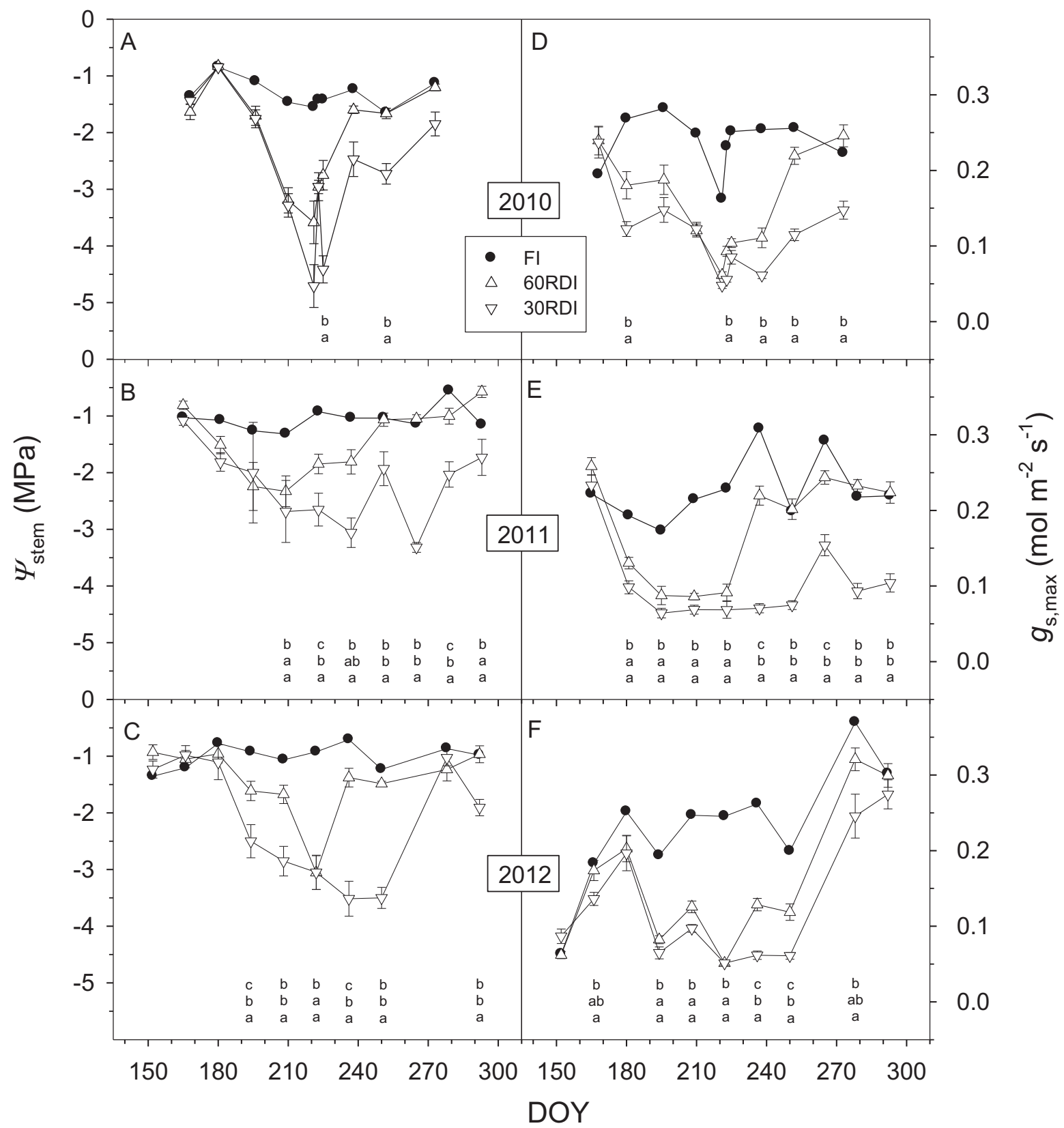

(For 2010 and 2011, DOY 150 = May 30; for 2012, DOY 150 = May 29) 


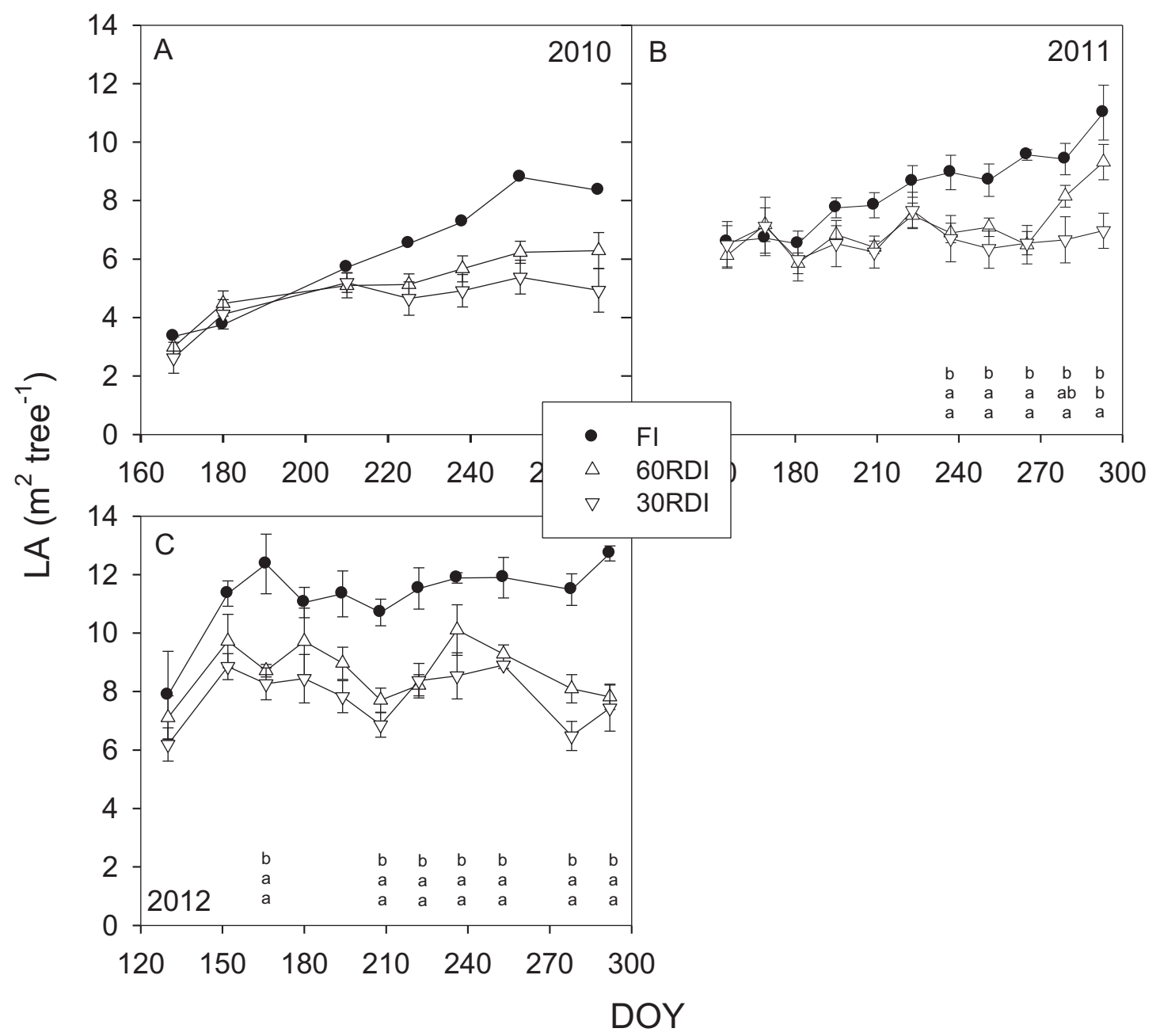

(For 2010 and 2011, DOY 150 = May 30; for 2012, DOY 150 = May 29) 
Table S1

Click here to download Electronic supplementary material: Table S1.docx 
Fig S1

Click here to download Electronic supplementary material: Fig S1.docx 